\title{
Considering Custom in the Making of Siyar (Islamic International Law)
}

\author{
Md (Muhammad) Anowar Zahid \& Rohimi B. Shapiee*
}

Custom is a source of Islamic law in general and Siyar (Islamic international law) in particular. Islamic jurists have set out the elements and conditions of customs for general jurisprudential purpose. However, no one has, to the authors' knowledge, formulated them from Siyar perspective. This paper is an attempt to fill this gap by tracing two important elements of an international custom, namely frequent and dominant general practice of States, and acceptance of that practice as law. These two will constitute a valid custom provided they fulfill certain conditions, most importantly that the custom must not conflict with Shari' ah or the spirit of Shari' ah.

\section{Keywords}

Custom, Islamic Jurisprudence, Siyar, International Custom, Opinio Juris

\section{Introduction}

Today custom ( 'urf $)^{1}$ is recognized as a source of Islamic law, especially by the Hanafi

* Faculty of Law, Universiti Kebangsaan Malaysia (National University of Malaysia). The authors may be contacted at: dr.anowar.zahid@gmail.com; rohimi_s@hotmail.com/Address: Faculty of Law, National University of Malaysia, UKM Bangi 43600, Selangor, Darul Ehsan, Malaysia.

1 The Arabic terms, 'urf and 'adah, are interchangeably used for custom. Some authors have made a distinction between them. For example, Imam Abu Hamid Muhammad al-Ghazali (450-505 A.H/1058-1111 C.E) meant by "urf and 'adah 'practices of Muslims' and 'God's custom in running the world' respectively. WAEL B. HALLAQ, LAW AND LEGAL THEORY III 343 (1999) cited in G. Libson, On the development of custom as a source of law in Islamic law, 4 IsLAMIC LAW \& SociETY 133 at n. 4 (1997). Muhammad Hashim Kamali has defined the former as "recurring practices that are acceptable to people of sound nature" and the latter as "(personal) habits of individuals." See M. H. KAMALI, PRINCIPLES OF ISLAMIC JURISPRUDENCE 369 (2003). As custom, in general, refers to common social practices this article uses the term in the sense of "urf in line with the connotations given by these two authors. 


\section{School of law. ${ }^{2}$ It is defined as "recurring practices that are acceptable to people of sound nature." 3 It took a long time for a custom to receive the recognition. ${ }^{4}$ First, a custom entered into the corpus of Islamic law as Sunnah (sayings, doings and approvals of the Prophet Muhammad). For example, the following rules have their roots in pre- Islamic customs: diyah (blood money payable by the relatives of a killer to the successors of the killed); salam transactions (advance payment for future goods); rahn (mortgage);}

2 There are four main (Sunni) Schools of Islamic jurisprudence- Hanafi School, Maliki School, Shafi-i School and Hanbali School- named after their founders. Imam Abu Hanifa (actual name was Nu' man bin Thabit), born in 80 A.H. and based in Iraq (Kufa), was the founder of the Hanafi School. Imam Malik bin Anas, born in 95 A.H. and based in Madina, was the founder of the Maliki School. Imam Muhammad bin Idris Al-Shafi-i, born in 150 A.H. in Gaza and finally based in Egypt, was the founder of the Shafi-i School. Imam Ahmad bin Hanbal, born in 164 A.H. and based in Iraq, was the founder of Hanbali School. These schools are a result of their differences with regard to the methodologies of lawmaking from the Shari' ah (core Islamic law) sources such as the Qur' an, Sunnah (saying, doings and approvals of Prophet Muhammad), Ijma' (consensus of Islamic jurists) and Qiyas (analogical deduction). Some of their leading features may be briefly stated as follows. Hanafi School takes the Qur'an as the principal source of Shari' ah. It does not accept normally any ahad Hadith (a Sunnah reported by one/two persons) because the authenticity of such Hadith, given the number of narrator, is not above question. If such a Hadith conflicts with the Qur'an, Hanafi School sticks to the Qur'an. For example, according to one ahad Hadith, no marriage (of women) is valid without the guardian's consent (Narrated by al-Tirmidhi, 1101; Abu Dawood, 2085; Ibn Maajah, 1881). Hanafi School does not take this Hadith. It relies on the Qur'an, which allows business transactions by women as well as by men, e.g., "Oh you (men and women) who believe! When you deal with each other in transactions..." (Qur' an, 2:282). It argues that in Islam marriage is a civil contract. If a business contract, which is a civil contract, can be accomplished by both men and women, why should women not be able to consent to their own marriages? Besides, there are instances of marriages without guardian during the Prophet's time and his Companions' time. Accordingly, Hanafi School allows marriage without the guardian's consent. On the other hand, Shafi-i School takes Sunnah as the explanation of the Qur'an. So, it accepts ahad Hadith even if it apparently contradicts with the Qur'an. As such, according to this school, marriage without the guardian's consent is not allowed. In Islamic lawmaking the Maliki School gives a special value to the practices of the people of Madinah in accepting Ahadith (plural of Hadith) because the Madinah people saw the Prophet and, therefore, were better knowledgeable of the Prophet's Sunnah. As such, if any Hadith was not supported by the Madinah practices, Imam Malik did not accept that. Contradistinguished with this, Imam Ahmad bin Hanbal accepted all Ahadith, weak or strong. Because Imam Abu Hanifa was extremely cautious about the authenticity of Hadith, he did not accept weak Hadith (Sunnah narrated by people of weak memory and low level of piety). He used and his school do use Qiyas extensively to make new laws (fiqh) out of the fundamental sources (the Qur' an and the Sunnah). On the contrary, other schools, especially Shafi-i and Hanbali Schools, make restrictive use of Qiyas. In interpreting the legal texts (the Qur' an and Sunnah) these three schools take a conservative approach, whereas Hanafis adopt a liberal approach. An ample example is the relevance of customs in the lawmaking process. Hanafi School takes custom as a formal source subject to the fulfillment of certain conditions, most importantly that a custom must not conflict with Shari' ah or the spirit of Shari'ah. Maliki School, as said above, attaches special importance to Madinah practices and customs. Other two Schools initially did not accept custom as a source of Islamic law. Of course, both Imam Al-Shafi-i and Imam Ahmad bin Hanbal acceded to the importance of people's practices at the later parts of their lives. However, over time custom has occupied a position, in a varying degree though, in all Schools of Islamic jurisprudence. In particular, the Hanafi School has crowned it with a very distinguished status. See Libson, infra note 4.

3 Kamali, supra note 1, at 369 .

4 For an excellent account of the development of custom as a source of Islamic law, see Libson, supra note 1, at 131.

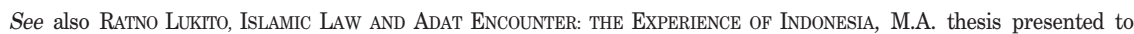
McGill University 5-37 (1997), available at http://www.collectionscanada.gc.ca/obj/s4/f2/dsk2/ftp03/MQ37218.pdf (last visited on Mar. 10, 2010). 
kafa' ah (equality requirement in marriage); and 'asabah (inheritance attached to the male line of inheritors). 5 Second, the custom came into use as a material in building Islamic law by jurists in the period from late 9th to 12th centuries. 6 Through frequent and consistent use over a long period of time the custom assumed the status of a legal source alongside the fundamental sources, which are the Qur'an, Sunnah, Ijma' (consensus of jurists) and Qiyas (analogical deduction). ${ }^{7}$ To quote the Hanafi jurist, Ibn Nujaym(d.970/1563):

Know that the consideration of custom and usage reappears frequently in law in many cases, so much that they [viz., the jurists] have transformed it into a legal source, and they said in the usul literature, in the chapter of abandonment of literal meaning: the literal meaning is abandoned on the basis of an indicator found in inferential methods of inquiry and in customs. 8

Ibn Nujaym's observation later received a State law status by setting forth principles relating to custom in The Mejelle (The Ottoman Civil Law). For example, "Custom is of force," 9 "Under the guidance of custom the true meaning is abandoned," 10 "Custom is only given effect to, when it is continuous or preponderant," 11 "A thing known by common usage like a stipulation which has been made," 12 "What is directed by custom is as though directed by law." 13

However, all customs do not have the legal force; only "qualified" customs have.

Kamali, supra note 1 , at 372 .

6 Jurists of this time took custom into consideration while applying the principles of istihsan (judicial preference) and darura (necessity). The former principle allows (a) preference for a recognized source of law over qiyas (juristic analogical deductions), or (b) preference for a strong qiyas over a weak one. J. Makdisi, $A$ reality check on istihsan as a method of Islamic legal reasoning, 2 UCLA J. ISLAMIC \& NEAR E.L 99. For example, the sale of a non-existent object was not allowable by qiyas, but there was a long standing practice of such sale among people, which Imam Shaybani (d. 189/804) took as a basis of his verdict. Id. at 117-126. The principle of darurah permits, in a situation of terrible hardship, modification of a legal injunction in order to avoid immediate harm. M. I. DIEN, ISLAMIC LAW: FROM Historical Foundations to CONTEMPORARY PraCtice 82 (2004). These tools of fiqh came into operation to meet the demands of the time with the expansion of the Islamic territory after the departure of the Prophet when 'disputes and legal questions relating to purely local matters were bound to be settled on the basis of the customs and precedent of each locality $\cdots[$ which] must have supplied the Muslim jurist with raw material on the strength of which he issued opinion whenever an authoritative text failed to provide an answer.' M. KHADDURI(TRANS.), THE HISTORICAL BACKGROUND OF THE RISALA' IN AL-SHAFI-I's RiSALA 4-5 (1987).

7 For discussion on the sources of Islamic law, see ANWAR AHMAD QADRI, ISLAMIC JURISPRUDENCE IN THE MODERN WORLD 174-222 (1973).

8 Libson, supra note 4, at 141 (footnotes omitted).

9 The Mejelle (English translation of Majallah El-Ahkam-i-Adliya), art. 36.

10 Id. at art. 40.

11 Id. at art. 41

12 Id. at art. 43.

13 Id. 
Qualified customs are those which satisfy the particular criteria set by jurists. A modern jurist Sobhi Mahmassani laid down the following criteria:14

Acceptability: A custom must be "acceptable to people of sound nature," meaning "it must be reasonable, and compatible with good sense and public sentiment."

Frequency: A custom must be a frequent and recurrent practice in common. In other words, the custom to be effective must be consistent and dominant. This means that with regard to a particular matter, for example a real estate sale, the usual practices of most of the people involved in this business will be given legal weight. If, for example, in real estate business more than one currency is accepted as a means of payment, the currency that is more usually used by most of the people in that business shall be accepted in absence of any written stipulation in this regard.15

Prevalence: It is important to see when the custom has come in prevalence. To receive effect in Shari'ah it must be in force at the time of or before the transactions. Customs developing afterwards are of no avail in relation to the transactions. Thus, for example, a customary rule will not be relevant to the interpretation of a commercial deed if that custom was not in practice at the time of its conclusion, rather developed later and became relevant at the time of interpretation because "it is generally assumed that documents which are not self-evident and require clarification can only convey concepts that were common at the time they were written." 16

Subordination to written stipulation: When there is a contract and particular conditions of it are not clearly stated, customary practices will fill the gaps of unwritten conditions. If, however, there are written stipulations, but customs contradict them, the former will take precedence over the latter. For example, it is a local custom to pay half of the dower money at the time of marriage and the rest at some subsequent time. The contract of marriage contains in writing that the full amount would be paid at the time of conclusion of marriage. This written condition shall replace the custom.

S. Mahmassani, Falsafat al-Tashri fi alislam: The Philosophy of Jurisprudence in Islam (F. J. Ziadeh trans.) 133134 (2000). Mahmassani is a modern jurist of Lebanese origin. He has practiced legal profession as an attorney, judge and professor. He is well versed in Islamic law and Western laws. The original work written in Arabic (Falsafat alTashri fi al-Islam) was published in 1946. The most important characteristic feature of this book is that it has, in brief, explored the original jurisprudential works of Islamic scholars of the past and has compared the old views with their modern (Western) counterparts. This is said to be an introduction to another two-volume book of his: AL-NAZARIYAH AL-AMMAH LI-AL-MUJIBAT WA-AL-UQUD FI AL-SHARI' AH AL ISLAMIYAH (1948). Today Mahmassani is taken to be as a leading authority of Islamic jurisprudence and hence his views deserve great value and respect.

15 Kamali, supra note 1 , at 373.

16 Id. at 373. 
Compatibility with Shari'ah: This is the prime condition for the acceptability of custom as a source of law. This may be termed as the religious condition and the rest mentioned above as the secular conditions. Customs that satisfy the secular requirements shall not be accepted in the domain of Islamic law if they are incompatible with the established legal sources (which include the Qur'an, Sunnah, and ijma) ${ }^{17}$ or the spirit of Shari' ah.

In Siyar18 or Islamic international law, custom is one of the important sources. A modern jurist Muhammad Hamidullah defined Siyar as follows: "[T]hat part of the law and custom of the land (a Muslim State) and treaty obligations which Muslim de facto or de jure state observes in its dealings with other de facto or de jure states (Muslim or nonMuslim)." 19 In this definition, Hamidullah has included three principal sources of Siyar, which are law, custom and treaty, along with some additional sources at another place.20 By 'law' he meant Figh, i.e. Islamic law emanating from the Qur'an, Sunnah and developed, on the basis of the Qur'an and Sunnah, by Ijma and Qiyas. ${ }^{21}$ Second, custom and usage that developed in international transactions may become a part of Siyar provided that certain requirements are met.22 Finally, treaties are conclusions of Muslim or non-Muslim States. Hamidullah has not, however, laid down requirements or criteria for customs which will qualify as law.

Therefore, this paper is an endeavour to fill this gap. In the first place, this paper will examine the custom requirements set by Mahmassani, which are enumerated above, in order to determine if the requirements may apply to Siyar or if there should be any additional requirement(s) in view of Siyar's reciprocal nature. 23 Second, after identifying

17 Customs contradicting qiyas still may prevail on the ground of istihsan or darurah or maqasid alShari' ah. See Mahmassani, supra note 14, at 132. See also Makdisi, supra note 6; Dien, supra note 6.

18 Imam Abu Hanifa (d. 150 H.) is known to have first titled Siyar for his lectures on Muslim Laws of War and Peace. After him, his students like Imam Abu-Yusuf, and Imam Muhammad As-Shaybani (d. 189 H.), and also Imam AshShafi' iy used the term in the same sense and for the same purpose. In this way over time Siyar has assumed the technical sense of Islamic International Law. Dr Hamidullah quotes As-Sharkhsiy (d. 483 H.) to evidence such an use of the term as follows:

Know that the word siyar is the plural form of Sirat. We have designated this chapter by it since it describes the behaviour of the Muslims in dealing with the Associators (non-Muslims) from among the belligerents as well as those of them who have made a pact (with Muslims) [and live as Resident Aliens or non-Muslim subjects]; in dealing with Apostates who are the worst of the infidels since, they abjure after acknowledgement (of Islam), and in dealing with Rebels whose position is less (reprehensible) than that of the Associators, although they be ignorant and in their contention on false ground. See M. HAMidullah, ISLAmic Worlds: INTER-STATE RElations 17 (2001).

19 Hamidullah, id.

20 Id. at 20.

21 Supra note 7.

22 Hamidullah, supra note 18, at 33.

23 Over time the reciprocity of treatments of parties in international relations has assumed a distinguished feature of 
the custom requirements for the Siyar purpose, this paper will make an attempt to define the custome requirements in further detail.

\section{A Brief Perusal of the Islamic Jurisprudential Criteria of Custom for the Purpose of Siyar}

In this section, the custom criteria under Islamic jurisprudence would be evaluated to see if they are adequate for the purpose of building Siyar. The jurisprudential criteria which are mentioned in above may be capsulized thus- a custom must be a frequent and dominant practice, which is reasonable, sensible and Shari' ah friendly. The custom must be in practice at or before the time of a transaction in relation to which the custom is called upon to apply. Plus the custom must not be in conflict with any written stipulation such as a contract. For the purpose of Siyar, those criteria may be restated as follows:

(a) a custom must be reasonable and sensible in the judgment of the Islamic State;

(b) it must be frequently and dominantly practiced in interstate relations in general;

(c) it must be in force at or before the time of an international transaction in relation to which its relevance is in question;

Siyar. This may be understood from a brief account of its historical development as follows. With the establishment of an Islamic State in Madinah by Prophet Muhammad (peace be upon him) Islam was increasingly spreading around the world. In this process Muslims had to encounter resistance by non-Muslim territories, which led to war. This was almost a daily affair of the Islamic State until the early Ottoman rule. The world got divided into dar al-Islam (Islamic territories) and dar al-harb (non-Islamic/war territories). Given this reality jurists of that time, especially the classical jurists, developed Siyar basically as a law of war, which included rules of war, cessation of war, distribution of booties, treatment of prisoners, law of revenue, etc. Of course, they also included the law of peace, such as peace treaty, diplomatic rights and privileges, and safe-conduct (aman) toward non-Muslim visitors or traders for a temporary period of time. See M. Khadduri, The Islamic LaW of Nations: Shaybant's Siyar 6 (1966). In this respect foreign relations of the Islamic State were reciprocal. Further examples may be found in the international relations maintained by Islamic State of later time, such as Caliph Harun al-Rashid (786-809 AD) had mutual and friendly relations with Charlemagne. H. Moinuddin, The Charter of the Islamic Conference and Legal Framework of Economic CoOPERATion AMONg ITs Member STAtes 38 (1987). Since the $16^{\text {th }}$ century dar al-Islam chose the "state of peace" as the permanent basis of its relations with the dar al-harb based on the principles of reciprocity and mutual interests. This is evident from the bilateral treaties between the Ottoman Empire and the European States: the Treaty of Carlowitz, the Russian-Ottoman Treaty for the Partition of Persia's Northwest Provinces, 1724; the Treaty of Peace (Belgrade), 1739; the Treaty of Peace, 1774; the Treaty of Peace (Jassy), 1792; the Treaty of peace (Bucharest), 1812. See Moinuddin, id. at. $40 \& 227$ (n.160). In addition to some other Muslim States like Persia, Morocco, Tunis, Muscat, the Ottoman Empire granted numerous commercial privileges to European States. For a long list of the privilege granting agreements, see Moinuddin, id. at 227-228 (nn.163-168). Thus reciprocity is an important aspect of Siyar, which Islam has contributed to modern international law. Gamal M. Badr, A Survey of Islamic international law, 56 Proc. of AM. SoC' y INT' L L. 59 (1982). 
(d) it does not contradict an interstate agreement or treaty provisions; and

(e) finally and most importantly, after fulfilling the above conditions, it must not be in conflict with Shari'ah or spirit of Shari'ah.

The above criteria may be classified into two categories: elements of a custom, and conditions for its application. Elements are the ingredients which make a custom together. Of all the above criteria, criterion (b) which is the frequent and dominant interstate practice is an element of an international custom. The other elements are the conditions which must be fulfilled before the custom is accepted as a rule by an Islamic State. The mere presence of a practice between two or more States will not make it a customary rule for any other State(s) unless the latter accepts it as binding upon itself subject to the fulfillment of all the conditions, most importantly friendliness with Shari' ah. Thus, there must be an initiation of a practice followed by acceptance, thereby turning the practice into law. As such, there are two main elements of a custom to have the force of law under Siyar:

(a) Frequent and dominant state practice at the international plane, and

(b) Acceptance of that practice as law

As noticed earlier, the element of acceptance of custom as law by an Islamic State is absent from Mahmassani's formulation of custom requirements. The reason is probably that Mahmassani formulated those requirements from municipal law perspective and hence did not feel necessity of including it. Within a State jurisdiction, the court of law may apply a custom of the majority people, which fulfills the necessary conditions, to settle a dispute between parties who may not be the actual participants in custom creation. Their consent to its creation is of no count. This is not the case with Siyar or international law, however, in which States are sovereign subjects. The salient feature of States' sovereign character is that they retain the right to independently accept or reject any international obligation. There is no super State above the others to legally impose anything on the other states. ${ }^{24}$ Here lies the significance of the requirement of acceptance of a custom as law in addition to its initiation: the reciprocity aspect of Siyar. 25

In this connection it may be noted that the two elements (frequent and dominant practices and acceptance) are similar to elements of international custom of (general) international law. According to Article 38(1)(b) of the Statute of the International Court of Justice ("ICJ"), in its determination of judicial disputes the ICJ shall apply, among

24 L. OPPENHEIM, InTERNATIONAL LAW 119 (1955).

25 Supra note 23. 
others, "international custom, as evidence of a general practice accepted as law." The statute basically defines international custom as a general practice of States, which has been accepted as law, either explicitly or implicitly, by those States for or against whom the ICJ is invoked to apply it. 26

\section{Elements of Customs for the Purpose of Siyar}

\section{A. Frequency and Dominance of Practice}

This element of custom in the context of Siyar, frequency and dominance of practice, purports to mean that to receive customary value of law a practice should be repeated in most of the States' (both Muslim and non-Muslim States) actions. In other words, the practice must be consistently carried out by States in general. However, all States need not participate. If the majority of States follow the same practice again and again, the requirement will be fulfilled. In this respect, Article 41 of The Mejelle is relevant. That article reads: "Custom is only given effect to, when it is continuous or preponderant." What is "preponderant" in this context? Article 42 of The Meielle defines: "[T]hat is esteemed preponderant which is commonly known and not that which rarely happens."

The words, "commonly known" may give two interconnected meanings in Siyar. First, the custom should be States' practice in general. Second, States should usually carry out the custom. Thus a custom may become preponderant or commonly known when States in general frequently participate in practicing the custom. For example, there was a practice of exchanging ambassadors in international relations even before the time of Prophet Muhammad (peace be upon him) as evidenced in the Qur' anic story of bilateral commissioning of emissaries by Prophet Sulaiman (Solomon) and the Queen Biqis of Seba.27 Ambassadors enjoyed respect, honour and privileges, even when they were from an enemy country. This custom has been followed by nations of the world for centuries.

Thus, international custom is a product of reciprocal acts of States. Reciprocity 28 is one of the leading features of Siyar, which has been implemented into present international law. ${ }^{29}$ As a result, "given the present structure of the international

\footnotetext{
26 For debates over the wording of Article 38(1)(d) of the Statute of the International Court of Justice, see K. WoLFKE, CUstom in Present International LaW 6-8 (1993). 
community, reciprocity is at the origin of all international law." 30 Because of this, the repeated practices of States in general are also an element of custom under international law of today. Additionally, the meaning of this element may appear at the following words of the International Court of Justice ("ICJ"):

The Court does not consider that, for a rule to be established as customary, the corresponding practice must be in absolutely rigorous conformity with the rule. In order to deduce the existence of customary rules, the Court deems it sufficient that the conduct of States should, in general, be consistent with such rules, and that instances of State conduct inconsistent with a given rule should generally have been treated as breaches of that rule, not as indications of the recognition of a new rule. 31

The element of frequent and dominant practice contains an implied element- time. The fact that a repeated practice ripens into a custom over time indicates that the custom should be of some age. This may be buttressed by the interpretation of the following verse of the Qur' an directing Prophet Muhammad (peace be upon him) to "command with "urf." 32 What is "urf in this context? This term may have two meanings.33 First, the term has a meaning of the monotheistic faith and religion of Islam. Second, in the absence of any clear command or prohibition in the Qur' an or Sunnah, the term has the other meaning of socio-cultural and religious practices, or customs, prevalent in Muslim or other monotheistic faith-based societies like Christian, Jewish societies, which are friendly with Islamic Shari' ah.

If the first meaning is taken, it will indicate that Islam which is a monotheistic faith is a traditional faith-based religion ( 'urf) as monotheism has been propagated by all prophets from time immemorial. Likewise, if the second meaning is adopted, this will still require a custom to be of some age because other monotheistic religions are timeold faiths, and therefore their socio-cultural and religions rules and behaviours are also time-old. Thus, whichever meaning of the term 'urf is accepted, it must indicate that age is an element of a valid custom in Islamic law in general and Siyar in particular.

\section{B. Acceptance of Custom as Law (Opinio Juris) ${ }^{34}$}

A State is a sovereign and independent entity. A State has the total freedom to accept or

30 Virally, Le Principe de Reciprocite dans le Droit Internationale Contemporain, 122 RecueIL Des CouRs 51 (1967), recited in Badr, supra note.23, at n.1.

31 Military and Paramilitary Activities (Nicar. v. U.S.) (Merits) 1986 I.C.J. (June 27) 14, para. 186. [Emphasis added]

32 Qư'an, 7: 199.

33 Abu Bakr Muhammad B. AL-ARABI, AhKam AL-QuRan 823-5 (2003), cited in Dien, supra note 6, at 65 (n. 46.).

34 Under modern international law the term, opinio juris is used to mean acceptance of custom as law. For Siyar purpose it is here used in the same sense. For the modern meaning and use of the term, see infra note 41. 
reject an international customary practice. The question is how to accept or reject. Answer to the former question is either explicitly or impliedly. This is established by the Qur' anic mode of acceptance or rejection of pre-Islamic rules, which are called, in one sense, 'urf (custom) in the language of the Qur' an.35 For example, the Qur' an explicitly enjoins the pre-Islamic command of fasting on Muslims: "O believers (Muslims), fasting is prescribed for you as it was prescribed for those who came before you." 36 On the other hand, the Qur' an mentions the rule of retribution which was prevalent among the Jews, but does not explicitly impose this command on Muslim. To quote the Qur'an: "[W]e ordained therein (Torah) for them life for life, eye for eye, nose for nose, tooth for tooth and wounds equal for equal." 37 Here, the Qur' anic reference to this rule without condemnation is taken as a command by implication imposed on Muslims, particularly according to Hanafi School of jurists. This interpretation may be supported by the Qur' anic style of disapproval of bad customs of pre-Islamic Arab society. For example, in pre-Islamic time female children were used to be buried as a sign of humiliation and misfortune; "When news is brought to one of them of (the birth of) a female (child), his face grows dark, and he is filled with inward grief!" 38 The Qur' an unequivocally disapproved this practice: "When the female (infant), buried alive, is questioned, for what crime she was killed." 39 The Qur' an prohibits all kinds of infanticide no matter what the child is a male or female: "Kill not your children on a plea of want. We provide sustenance for you and for them. Come not near shameful deeds, whether open or secret. Take not life which Allah has made sacred." 40 Thus, by copying the Qur' anic style it may be argued, on the international plane a custom, if Shari' ah-friendly, may be accepted by express words or actions or by implied means (i.e., by toleration of a practice). Furthermore, if the custom is not Shari' ah-friendly, it must be expressly condemned. Therefore, the express and implied acceptance will create obligations for the [accepting] State while the clear objections will not. 41

The modes of acceptance and condemnation of customs were practiced by the Prophet himself. By his verbal words, physical actions, or tacit approvals, he accepted some of the pre-Islamic customs and rejected others, or introduced new rules of

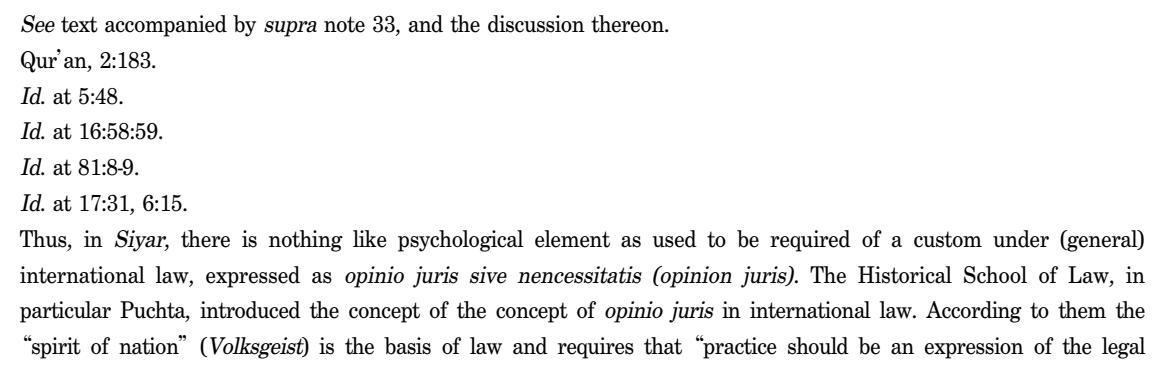
international law, expressed as opinio juris sive nencessitatis (opinion juris). The Historical School of Law, in particular Puchta, introduced the concept of the concept of opinio juris in international law. According to them the "spirit of nation" (Volksgeist) is the basis of law and requires that "practice should be an expression of the legal 
conduct. The most important customary practice approved by the Prophet in international relations is the exchange of diplomatic emissaries. There was a practice of exchanging ambassadors in international relations even before the Prophet. The practice has been evidenced in the Qur' anic story of Prophet Sulaiman and Queen Bilqis, which is mentioned earlier. The Prophet accepted this practice and he himself sent and received ambassadors. The Kings/Governors to whom he sent ambassadors included Hercleus, the Emperor of Byzantine, Chosroes II, the Emperor of Persia, Negus, the King of Abyssinia, and Muqawqis, the Ruler of Egypt.42 The Prophet invited them to accept Islam. On another occasion, the Prophet commissioned Harith bin Umayer, as his ambassador to the King of Busra, Shurahbil. Harith was killed by the ruler of Muta. Obviously aggrieved at the breach of this long standing international customary rule, the Prophet ordered an army to advance against the King under the leadership of Zayed bin Haritha. 43 There are numerous instances where the Prophet received and showed respect and privileges to foreign ambassadors. 44

With regard to the incumbent issue, the Prophet's following words are also relevant: "Whatever Muslims consider to be good is good in God's sight." 45 "Muslims," in the context of Siyar, may refer to Muslim States inter se or Muslim States and non-Muslim States. 'Agree' may mean express consent or acquiescence. "Whatever Muslims

conscience of the nation." In international law this requirement has been adopted in the meaning that "practice be followed by a feeling of doing one's duty or doing what is right." Wolfke, supra note 26, at 46. Because this "feeling" is difficult to establish the ICJ has given mere lip-service to it; it has been "less concerned with the analysis of mental states than with the examination and assessment of the facts proved." See M. VIRALly, THE SOURCES OF InTERNATIONAL LaW In Manual of Public International LaW 134-135 (1978), cited in Wolfke, supra note 26, at 50. What it has done is "to determine whether or not they (the facts of the cases) disclose an effective exercise by a State of right, coupled with recognition by another State of corresponding obligation." See Wolfke, supra note 26, at 50. As such over time the opinio juris has been increasingly divorced of its psychological character and has "more and more unequivocally equated with the requirement of acceptance of the practice as law by the States to be bound by the customary rule.' Wolke, supra note 26, at 170. Thus today international customs are created by States' "qualified practice" (i.e., general and consistent practice over some time), which is an 'expression of law,' on the one hand and simply an express or implied "acceptance" of the practice as law by all interested States on the other. Wolfke, supra note 26, at 51. If a State does not want to endorse a practice, it must persistently object to it and thereby can avoid its application to itself. Brownlie, Principles of Public International LaW 10 (1990). See also Asylum case (Columbia v. Peru) 1950 I.C.J. 266 \& 272-78; Fisheries Case (U.K. v. Nor.) 1951 I.C.J. $116 \& 124-31$.

42 See http://www.prophetmuhammadleadership.org/prophet_muhammad_style_of_commun\%20as\%20world\%20leader.htm (last visited Jan. 25, 2009).

43 See Could you give information about the battle of Muta?, available at http://islambyquestions.net/moreAbout/ Muta.htm (last visited Jan. 25, 2009).

44 J. Rehman, Islamic State Practices, International Law and Threat from Terrorism: A Critique of the 'Clash of Civilizations' in THE NeW WORLD ORDER 188-189 (2005).

45 Some claim, however, that this is a saying of Abdullah ibn Mas'ud, one of the leading Companions of the Prophet. See Kamali, supra note 1, at 241 and the accompanying note. 
consider to be good" may connote that Muslim States have considered a custom friendly with Shari' ah. Also, "good in the sight of God" may imply that the custom considered by Muslim States to be Shari' ah-friendly is acceptable. So, the tradition of the Prophet in the present case may mean that if there is a custom between Muslim States inter se, or between Muslim States and non-Muslim States, and Muslim States expressly or impliedly accept that custom because it is not against Shari' ah, that may be a valid custom from Islamic perspective. In other words, it may be said that customs accepted by Muslim States in their international life must be respected because their acceptance creates legal obligations for the States.

Thus, in order to create legal obligations, a custom must be expressly or impliedly accepted by Muslim States if it satisfies the requirements and conditions discussed above. The most important of the requirements and conditions is the Shari'ahfriendliness of the custom. In the event of the custom's failing to meet the requirements and conditions, they should refrain from endorsing it. Even more, they should persistently protest against the custom which fails to meet the requirements and conditions, and thereby keep themselves outside the purview of its application. If they do not so protest, that may create implied liability for them.

\section{Conclusion}

A special feature of modern Siyar is reciprocity in international lawmaking, which is not shown in the domestic law. International lawmaking is different from domestic lawmaking particularly with respect to custom. At a domestic jurisdiction, a social usage may ripen into a custom through its consistent and dominant practice by a majority of people over some period of time. Domestic courts of law may apply that custom against a party/parties) who was/were not an actual participant(s) in its creation provided some other conditions are fulfilled.

Unlike the domestic law, however, the Siyar is reciprocal in nature. Siyar rules, either conventional or customary, cannot be imposed on a State without its consent. Here lies the importance of express or implied acceptance of custom (opinio juris). Thus, for Siyar jurisprudence there are two main elements for international custom: (a) frequent and dominant State practice over some period of time, and (b) acceptance of that practice as law (opinio juris). Additionally, before accepting an international custom that fulfill the two elements in Siyar, an Islamic State must be satisfied that the following conditions have been met: (i) that the practice is not opposed to human reason and conscience; (ii) 
that the practice does not contravene any of its treaty obligations; and (iii) that it does not conflict with Shari' ah and its spirit. If any of these conditions is not satisfied, the State should persistently object to the practice and thereby absolve itself from its application. 
